\title{
KONDISI LINGKUNGAN SOSIAL DAN PSIKOLOGI LANSIA DI PANTI JOMPO HUSNUL KHOTIMAH PEKANBARU
}

\author{
Nurvi Susanti ${ }^{1}$, Nofri Hasrianto ${ }^{2}$ \\ S1 Kesehatan Masyarakat ${ }^{1,2}$, \\ STIKes Hang Tuah Pekanbaru ${ }^{1}$, STIKes Al Insyirah Pekanbaru ${ }^{2}$ \\ nurvisusanti83@gmail.com ${ }^{1}$, nofrihasrianto@gmail.com ${ }^{2}$
}

\begin{abstract}
The age of the elderly is the last stage of development in the cycle of human life. Physical development can stop until adolescence, but psychological, social and spiritual development never stops. Psychological disorders that are often experienced by older people in nursing homes include depression, anxiety disorders, sleep disturbances, dementia, Alzheimer's disease, diagnostic syndromes and can lead to dependence on others. people. This study aims to describe the state of the social environment consisting of the interaction between the elderly, the interaction between the elderly and managers, social activities, the interaction between the elderly and their families and the psychological state of the elderly in the environment of the retirement home in Husnul Khotimah. Pekanbaru when the research was conducted in July 2020. Descriptive survey research method., Research subjects were selected using the Total Sempling technique, the population was 70 elderly, while the sample was 35 people elderly, with inclusion and exclusion criteria. Data collection in this study using a questionnaire sheet. Data analysis using descriptive analysis. The results showed that the social environment of the elderly was mainly $22(63 \%)$ in the sufficient category. The psychological state of the elderly was mainly 34 (97\%) with sufficient category. It can be concluded that the results of the processed data are a description of the environmental, social and psychological conditions of the elderly in the Husnul Khotimah Pekanbaru social institution with fairly good results
\end{abstract}

Keywords : Environment, Nursing Home, Psychological, Social

\begin{abstract}
ABSTRAK
Usia lansia merupakan tahap akhir perkembangan pada daur kehidupan yang dialami manusia. Perkembangan fisik bisa saja berhenti sampai masa remaja, tetapi perkembangan psikologis, sosial, dan spiritual tidak akan pernah berhenti sampai akhir kehidupan manusia. Gangguan psikologis yang sering dialami oleh lansia dipanti jompo antara lain depresi, gangguan kecemasan, gangguan tidur, dementia, alzheimer, sindroma diagnosis dan dapat berakibat ketergantungan kepada orang lain. Penelitian ini bertujuan untuk mengetahui gambaran kondisi lingkungan sosial terdiri dari Interaksi sesama lansia, interaksi lansia dengan pengelola, aktivitas sosial, interaksi lansia dengan keluarga dan kondisi psikologis lansia dilingkungan panti jompo Husnul Khotimah Pekanbaru. Waktu penelitian dilaksanakan pada bulan Juli 2020. Metode penelitian survey deskriptif, subjek penelitian dipilih dengan menggunakan teknik Total Sempling, jumlah populasi lansia di panti jompo Husnul Khotimah Pekanbaru sebanyak 70 lansia sedangkan sampel sebanyak 35 lansia, dengan kriteria inklusi dan ekslusi. Pengumpulan data pada penelitian ini menggunakan lembaran kuesioner. Analisis data menggunakan analisis deskriptif. Hasil penelitian menunjukkan bahwa lingkungan sosial lansia sebagian besar sebanyak 22 (63\%) dengan kategori cukup. Kodisi psikologis lansia sebagian besar sebanyak 34 (97\%) dengan kategori cukup. Dapat disimpulkan hasil olahan data yaitu gambaran kondisi lingkungan sosial dan kondisi psikologis lansia di lingkungan panti sosial Husnul Khotimah Pekanbaru dengan hasil cukup baik.
\end{abstract}

Kata Kunci : Lingkungan, Panti Jompo, Psikologis, Sosial 


\section{PENDAHULUAN}

Continuum of care merupakan salah satu pelayanan kesehatan yang mengatur tentang pelayanan bagi lansia. Pelayanan kesehatan tersebut harus sesuai dengan standar yang akan dilaksanakan oleh tenaga kesehatan, baik di puskesmas, posyandu dan panti jompo (Kesehatan, 2013). Pelayanan kesehatan masyarakat terjadi perubahan diberbagai pihak khususnya tingkat derajat kesehatan masyarakat, pola dan kecenderungan penyakit dan meningkatnya tingkat inteligensi yang erat kaitannya dengan status gizi masyarakat.

Proses penuaan merupakan suatu proses alamiah yang tidak dapat dicegah tetapi merupakan hal yang wajar dialami oleh lanjut usia. Dimana semua orang berharap dapat menjalankan hidup dengan tenang, damai bersama anak, menantu, keluarga, dan cucu dengan penuh kasih sayang. Proses menua yang dialami lansia adalah proses alami disertai adanya penurunan kondisi fisik biologis, psikologis dan sosial. Kondisi tersebut membuka kesadaran perlunya langkah yang tepat agar posisi lansia secara demografis tidak membuka permasalahan baru, tetapi diharapkan dapat menjadi bagian komponen potensi untuk mengatasi berbagai permasalahan yang ada di masyarakat (Kuntjorowati, E. 2018).

Berdasarkan jumlah penduduk lansia di Indonesia mengalami peningkatan setiap tahunnya pada tahun 2019 sebanyak 25,9 $(9,7 \%)$ juta jiwa , tahun 2020 sebanyak $28,8(11,34 \%)$ juta jiwa, diprediksi akan terus mengalami peningkat pada tahun 2035 mencapai 48,2 (15,8\%) juta jiwa (Kemenkes 2020). Data lanjut usia di Provinsi Riau tahun 2018 sebanyak 11.156 lansia dan pada tahun 2019 sebanyak 11.217 lansia, sedangkan jumlah lansia di kota Pekanbaru tahun 2018 sebanyak 56.430 dan pada tahun 2019 sebanyak 60.666, (Badan Pusat Statistik, 2019).

Berdasarkan jumlah lansia yang setiap tahun mengalami peningkatan maka akan munculnya permasalahan, kenyataanya banyak orang yang berusia 60 tahun ke atas digolongkan orang lanjut usia sehingga tidak mengherankan jika pada usia tersebut mereka sering terabaikan dan bahkan dimasukkan ke panti jompo. Di sinilah pentingnnya adanya panti werda sebagai tempat untuk pemeliharaan dan perawatan bagi lansia (Elvina, 2012).

Menurut undang-undang Nomor 13 Tahun 1998 tentang Kesejahterahan Lanjut adalah seseorang yang mencakup usia 60 tahun keatas baik pria maupun wanita. Kualitas hidup lansia dipengaruhi berbagai faktor seperti kesehatan fisik, kesehatan psikologis, hubungan sosial dan lingkungan (Kiik, S. M., dkk. 2018). Kualitas rumah dan lingkungan yang bersih, sehat dan terjaga serta nyaman, hal ini akan mempengaruhi kondisi kesehatan orangorang yang tinggal didalamnya menjadi lebih baik pula (Kushariyadi, 2012).

Gangguan psikologis yang sering dialami oleh lansia antara lain depresi, gangguan kecemasan, gangguan tidur, dementia, alzheimer dan sindroma diagnosis. Gangguan psikologis pada lansia ini dapat menyebabkan suatu keadaan ketergantungan kepada orang lain (Setyowati, R. 2019). Faktor-faktor yang mempengaruhi terjadinya depresi meliputi faktor biologik, faktor fisik, faktor psikologik, dan juga faktor sosial. Faktor luar Kurangnya social support, dukungan keluarga, lingkungan, dan tersedianya komunitas untuk lansia juga menyebabkan depresi, sehingga masih banyak ditemukan lansia yang mengalami depresi, (Pae, 2017). Depresi merupakan gangguan alam perasaan yang berat dan ditandai dengan gangguan fungsi fisik dan fungsi sosial yang hebat, lama dan menetap pada individu tersebut (Yosep, 2009). Gejala penyerta depresi tersebut adalah perubahan pada pola tidur dan nafsu makan, psikomotor, konsentrasi, kelelahan, rasa putus asa dan tidak berdaya, serta bunuh diri (Kaplan, 2010).

Populasi lansia di Indonesia diprediksi meningkat lebih tinggi pada populasi lansia di wilayah Asia dan global setelah tahun 
2050, oleh karena itu panti jompo menjadi salah satu solusi untuk menitipkan orang tua yang telah lansia. Salah satu pelayaan kesehatan yang di fasilitasi oleh pemerintah yaitu panti jompo. Panti jompo merupakan sebuah rumah atau tempat (kediaman) yang menampung, merawat atau tempat berkumpulnya orang-orang lanjut usia, baik secara sukarela ataupun diserahkan oleh pihak keluarga untuk diurus segala keperluannya. Panti jompo ada yang dikelola oleh pemerintah maupun pihak swasta (Putri, Fitriana, \& Ningrum, 2015).

Hasil observasi peneliti pada panti jompo Tresna Werdha Husnul Khotimah Pekanbaru diperoleh bahwa ditemukan beberapa lansia dengan kondisi sakit parah (penyakit kronis) banyak diantara lansia mengalami penyakit lebih dari satu penyakit bahkan ada beberapa lansia yang terkena depresi. Kondisi sosial yang di alami, tidak mau bergaul dan tidak mau bersosialisasi dengan lansia lainnya yang ada di panti jompo. Permasalah ini dapat diatasi atau dihilangkan dengan kehidupan spiritualitas yang kuat (Stanley \& Beare, 2012).

Penelitian ini bertujuan menganalisis kondisi lingkungan sosial dan kondisi psikologis lansia di panti jompo Husnul Khotimah Pekanbaru

\section{METODE}

Penelitian ini bersifat deskriptif. Populasi dalam penelitian ini adalah semua lansia yang berada dipanti jompo Husnul Khotimah Pekanbaru, waktu pada penelitian dilaksanakan April tahun 2020, populasi sebanyak 70 lansia dengan jumlah sampel sebanyak 35 dengan menggunakan teknik total sampling dengan kriteria inklusi yaitu 1). Lansia binaan yang tinggal di panti jompo Kusnul Khotimah Pekanbaru 2). Dapat berkomunikasi dengan baik. 3). Berada ditempat saat penelitian dilakukan, 4). Bersedia menjadi responden. Sedang kriteri ekslusi yaitu lansia dalam keadaan sakit atau dirawat di Rumah Sakit .
Pengambilan data dilakukan dengan menggunakan lembaran kuesioner.

Variabel penelitian ini terdiri kondisi lingkungan sosial dan kondisi psikologis. Analisis yang digunakan yaitu analisis deskriptif lansia, dikategorikan menjadi 3 kategori penilaian yaitu jika baik dengan nilai sebesar 68\%-100\% yaitu merasa senang berinteraksi dengan sesama lansia. Variabel jika cukup baik dengan nilai sebesar 34\%-67\% yaitu mudah sekali marah jika orang lain menjengkelkan dan kurang baik dengan nilai sebesar (0\%-33\%) yaitu kecewa jika orang lain membicarakan dibelakang. Data diambil secara deskriptif yaitu dengan cara menyebarkan kuesioner kepada responen, analisis yang digunakan yaitu analisis deskriptif

\section{HASIL}

Analisis lingkungan sosial panti jompo Husnul Khotimah Pekanbaru

Tabel 1. Distribusi Fekuensi Variabel Lingkungan Sosial Panti Jompo Husnul Khotimah Pekanbaru

\begin{tabular}{ccccc}
\hline $\begin{array}{c}\text { Variabel } \\
\text { Penelitian }\end{array}$ & Skor & $\mathrm{f}$ & $\%$ & Kategori \\
\hline & $68-$ & 13 & 37 & Baik \\
& 81 & & & \\
Lingkungan & $44-$ & 22 & 63 & Cukup Baik \\
Sosial & 62 & & & Kurang Baik
\end{tabular}

Bersarkan Tabel 1. diperoleh hasil olahan data kondisi psikologis lansia pada panti jompo Husnul Khotimah Pekanbaru sebagian besar sebanyak $22(63 \%)$ dengan skor nilai 44 sampai 62 dengan kategori cukup baik yaitu interaksi lansia sesama lansia

Analisis Kondisi Psikologis Lansia Di Panti Jompo Husnul Khotimah Pekanbaru

Tabel 2. Distribusi Fekuensi Variabel Kondisi Sosial lansia di panti jompo Husnul Khotimah Pekanbaru 


\begin{tabular}{lcrrc}
\hline $\begin{array}{c}\text { Nama Panti } \\
\text { Jompo }\end{array}$ & Skor & \multicolumn{1}{c}{ F } & $\%$ & Kategori \\
\hline Kondisi & 72 & 1 & 3 & Baik \\
Psikologis & $37-65$ & 34 & 97 & Cukup Baik \\
& 0 & 0 & 0 & Kurang Baik \\
\hline
\end{tabular}

Bersarkan Tabel 2. diperoleh hasil kondisi psikologis lansia pada panti jompo Husnul Khotimah Pekanbaru sebagian besar sebanyak 34 (97\%) dengan skor nilai 37 sampai 65 dengan kategori cukup baik yaitu motivasi lansia.

\section{PEMBAHASAN}

\section{Lingkungan Sosial Panti Jompo Husnul Khotimah Pekanbaru}

Berdasarkan hasil penelitian lingkungan sosial panti jompo Husnul Khotimah Pekanbaru diperoleh dengan kategori cukup baik. Hasil penelitian sejalan dengan Keswara, 2017 lingkungan sosial dengan kesepian pada lansia Di UPTD Panti Sosial Lanjut Usia Tresna Werdha Kecamatan Natar Kabupaten Lampung Selatan dengan p-value 0,020 , dan didapatkan nilai OR sebesar 0,318 termasuk dalam kategori 0,20 - 0,399 yang artinya kekuatan korelasi antara interaksi sosial lansia dengan kesepian masuk dalam kategori cukup lemah. Diperkuat dengan hasil penelitian (Purnama \& Suhada, 2019) dengan jumlah responden 58 orang lansia, menyatakan: "Panti Jompo memiliki banyak kegiatan yang tersedia untuk para lansia, namun, masih ada beberapa lansia yang tidak berpartisipasi dalam program yang ada di panti.

Berdasarkan analisis peneliti lingkungan sosial cukup baik pada kedua panti jompo dikarenakan sebagian lansia dengan kondisi fisik dan psikis yang terganggu akibat faktor usia, pikun dan depresi sehingga lansia tidak bisa mengikuti semua kegiatan yang sudah dijadwalkan di lingkungan panti jompo. Begitu juga dengan interaksi lansia sesama lansia yang ada di lingkungan panti jompo yang sebagian cukup terjalin disebabkan karna terjadinya konflik atau pertengkaran seperti lansia merasa temannya sombong, kurang etika, tidak mau menjaga kebersihan wisma, merasa uang hilang dan dicuri, pertengkaran kipas angin, TV dan fasilitas lainnya yang ada diwisma, sehingga lansia tidak mau tegur sapa. Sedangkan interaksi yang terlihat cukup terjalin ada menolong teman yang sakit, beberapa lansia saling mengunjungi ke wisma lain untuk bercerita, bermain (domino, catur, kartu) untuk menghilangkan kejenuhan berada di lingkungan panti jompo. Untuk kegiatan rekreasi lansia merasa semejak pengelola yang baru lansia tidak pernah lagi dibawa pergi rekreasi, sehingga sebagian lansia berasumsi pengelola sekarang korupsi. Interaksi lansia dengan keluarga berjalan cukup baik, walaupun keluarga jarang berkunjung, tetapi keluarga berupaya menghubungi lansia dengan cara menelepon. Begitu juga dengan lansia yang memiliki hp berupaya menghubungi keluarga atau anak dan cucunya untuk melepas rasa kangen.

Peneliti merekomendasi untuk meningkatkan lingkungan sosial dengan baik perlunya meningkatkan aktivitas atau kegiatan harian lansia seperti adanya kegiatan kesenian seperti perlombaan bernyayi, perlombaan permainan catur atau domino yang rutin dilakukan di panti jompo agar lansia dapat sering berkumpul dan saling berinteraksi satu sama lain. Begitu juga dengan kondisi psikis lansia yang terganggu sehingga lansia tidak dapat melakukan interaksi dengan lansia lainnya. Oleh sebab itu lansia membutuhkan pelayanan perawatan kesehatan dari segi fisik, psikologis, spiritual, maupun sosial.

Kegiatan rekreasi pada panti jompo Husnul Khotimah Pekanbaru perlu di adakan kembali dimana kegiatan rekreasi yang sudah 3 tahun tidak pernah diadakan lagi, peneliti menyarankan kegiatan rekreasi kembali diadakan minimal 1 kali setahun. Manfaat rekreasi tersebut dapat berdampak pada kesehatan fisik dan mental lansia dan memberikan hiburan dan kebahagian pada lansia serta dapat 
menghilangkan kejenuhan pada lansia selama berada di panti jompo. Sehingga lingkungan sosial yang ada di panti jompo akan lebih baik dirasakan oleh semua penghuni yang ada di panti jompo tersebut.

\section{Kondisi Psikologis lansia panti Jompo Husnul Khotimah Pekanbaru}

Berdasarkan hasil penelitian kondisi psikologis lansia panti jompo Husnul Khotimah Pekanbaru diperoleh dengan kategori cukup baik

Menurut Lopes, 2016, kondisi psikologis dimana adanya perubahan sistem dalam tubuh terjadi seiring bertambahan usia seseorang. Akibat dari perubahan yang terjadi pada lansia adalah menurunnya fungsi kognitif. Penelitian yang dilakukan Sari, et.al. 2018 bahwa lansia yang termasuk kategori early demensia dengan presentasi 38,8 \%. Gangguan fungsi kognitif disebabkan gangguan saraf pusat yang berdampak pada timbulnya penyakit. Gangguan konitif ini meliputi atensi, kalkulasi, visuospasial, bahasa, dan memori dapat berakibat terjadinya perubahan kepribadian, gangguan memori, orientasi, dan sulit mengambil keputusan. Jika hal ini berlanjut secara progresif maka dapat terjadi demensia (Williams, 2012).

Permasalahan mengenai perubahan terkait usia pada proses penuaan yang dapat menurunkan fungsi kognitif (memori) pada lansia perlu diprioritaskan, karena pada lansia yang semakin bertambah usianya diharapkan fungsi daya ingatnya dapat terpelihara dengan baik sehingga fungsi dan kualitas hidup lansia sebagai individu dapat terjaga dan terpelihara. Proses mental yang meliputi penyimpanan informasi dan pengetahuan yang semuanya terpusat di dalam otak (Kushariyadi, 2013).

Stimulus dari luar dapat berupa kejadian sehari-hari, disebut juga sebagai memori sensorium, memori sensorium cepat hilang kecuali diberi perhatian terhadap stimulus tertentu (Siregar, 2020). Terdapat beberapa tahapan terjadinya memori yang banyak dianut, yaitu pembentukan, penyimpanan dan pemanggilan memori. Pembentukan diawali stimulus-stimulus dari dalam diri maupun dari luar. Stimulus dari dalam diri, berguna untuk mempertahankan kehidupan dasar. Misalnya, mengingat tanda-tanda haus dan lapar atau yang lain (Duzel, Praag, \& Sendtner, 2016).

Berdasarkan hasil penelitian Kushariyadi, 2016. Permasalahan di Unit Pelaksana Teknis (UPT) Pelayanan Sosial Lanjut Usia (PSLU) Kabupaten Jember terdapat penurunan fungsi daya ingat pada lansia seperti; kesulitan mengingat waktu, hari, tanggal, bulan, tahun, alamat, tempat, benda, kesulitan mengingat kembali kejadian yang baru saja terjadi. Kesulitan mengingat waktu atau jam ketika ditanya tentang jam berapa saat ini. Kesulitan mengingat hari apa sekarang ini, sulit mengingat alamat rumah sendiri, kesulitan mengingat benda. Sulit mengingat kembali kejadian yang baru saja dialami. Permasalahan ini sering mengakibatkan menurunnya daya ingat pada lansia yang dialami dan dirasakan sudah sejak lama. Oleh sebab itu perlu dilakukan pemberian slow-stroke back massag.

Berdasarkan analisis peneliti terkait kandisi psikologis dari aspek memori sebagian lansia dapat mengingat seperti waktu sholat, jadwal makan, kadangkadang lupa dalam meletakan barang (kunci kamar), sebagian lansia dapat menyebutkan jam berapa sekarang, ingat nama anak dan keluarga. Hal ini dikarenakan faktor usia dan penyakit yang di alami lansia seperti hipertensi, struk, diabetes dan demensia, penyakit umum terjadi pada usia tua, dan merupakan sebuah gangguan penurunan fungsi otak, seperti daya ingat, kemampuan berpikir, memahami sesuatu, dan lain-lain.

\section{KESIMPULAN}

Berdasarkan uraian dan analisis yang penulis muat di dalam artikel ini maka dapat disimpulkan kondisi lingkungan sosial dan kondisi kesehatan secara psikologis pada lansia di panti jompo Husnul Khotimah Pekanbaru 
dengan hasil kondisi cukup baik. Berdasarkan analisa peneliti faktor usia yang sudah lanjut dapat menghambat lansia dalam melakukan interaksi sosial dilingkungannya akibat timbulnya penyakit yang di alami lansia seperti hipertensi, strok, diabetes dan demensia, yang merupakan sebuah gangguan penurunan fungsi otak yang dialami oleh lansia.

\section{UCAPAN TERIMAKASIH}

Kepada kepala atau staf PSTW Husnul Khotimah Pekanbaru, ketua STIKes Hang Tuah Pekanbaru, responden dalam penelitian ini yang telah memberikan berbagai masukan atau informasi, sehingga tulisan ini dapat disajikan. Penulis menyampaikan terimakasih kepada Yayasan Hang Tuah Pekanbaru melalui P3M STIKes Hang Tuah Pekanbaru telah mendanai penelitian ini.

\section{DAFTAR PUSTAKA}

Badan Pusat Statistik. (2019) Katalok Publikasi https://www.google.com/search?q=bps+ 2019

Duzel E., Praag, V, H., \& Sendtner M. (2016) Can Physical Exercise In Old Age Improve Memory And Hippocampal Function?. Brain 016 Mar; 139(3): 662673. Published Online 2016 Feb 11. Doi: 10.1093/Brain/Awv407 Pmcid: Pmc4766381 Mid: 26912638

Ervina, I. 2012. Kebutuhan Psikologis Para Lanjut Usia Di Panti Sosial Tresna Werdha Kasiyan Puger. Jurnal from UMJ

Kaplan H.I., Sadock B.J., Grebb J.A. (2010) Sinopsis Psikiatri: Ilmu pengetahuan Perilaku Psikiatri Klinis. 2nd ed. Jakarta: Bina Rupa Aksara

Keliat,dkk. (2011). Manajemen Kasus Gangguan Jiwa. Jakarta:EGC

Kementrian Kesehatan RI. (2020). Jumlah Penduduk Lansia Diprediksi Capai 48 Juta Jiwa. https://databoks.katadata.co.id/datapublis h /2020/05/29/jumlah-penduduk-lansiadiprediksi-capai-48-juta-jiwa-pada-2035

Kesehatan, D. (2013) Buku Profil Kesehatan Kabupaten Cilacap. Continuum Of Care. Cilacap.
Keswara, Romayati, U. (2017) Hubungan Interaksi Sosial Lansia Dengan Kesepian Pada Lansia Di Upt Panti Sosial Usia Lanjut Kecamatan Natar Kabupaten Lampung Selatan Tahun 2015jurnal Kesehatan Holistik (The Journal Of Holistic Healthcare),Volume 11, No.1, Januari 2017:1-4

Kuntjorowati, E. (2018) Comfortable and Peaceful at Budi Dharma ElderlyHome Service. Jurnal Penelitian Kesejahteraan Sosial, 16(2), 209-222.

Kushariyadi, (2016) Perawatan Daya Ingat Lansia Menggunakan Slow-Stroke Back Massage Di Unit Pelaksana Teknis Panti Sosial Lanjut Usia Kabupaten Jember NurseLine Journal Vol. 1 No. 1 Mei 2016 ISSN 2540-7937

Kushariyadi, 2013 Intervensi (Stimulasi Memori) Meningkatkan Fungsi Kognitif Lansia (Memory Stimulation) Intervention Increase Elderly Cognitive Function. Jurnal Ners. Vol 8 No 2 Oktober 2013.

Kushariyadi. (2012) Asuhan Keperawatan Pada Klien Lanjut Usia. Penerbit Salemba Medika, Jakarta

Lopes, M. A., Xavier, A. J., \& D’Orsi, E. (2016) Cognitive and functional impairment in an older community. Archives of Gerontology and Geriatrics, pp. 134-139.

Maryam dkk.(2012). Mengenal Usia Lanjut dan Perawatannya. Jakarta: Salemba Medika

Maryam, R. Siti dkk. (2011) Mengenal Usia Lanjut dan perawatannya. Jakarta

Pae, K. (2017). Perbedaan Tingkat Depresi Pada Lansia Yang Tinggal Di Panti Werdha Dan Yang Tinggal Di Rumah Bersama Keluarga. Jurnal ners lentera, 5(1), 21-32.

Purnama, H \& Suhada, T. (2019) Tingkat Aktivitas Fisik Pada Lansia Di Provinsi Jawa Barat, Indonesia Jurnal Keperawatan Komprehensif Vol. 5 No. 2, Juli 2019: 102-106.

Putri, S. T., Fitriana, L. A., \& Ningrum, A. (2015) Studi Komparatif: Kualitas Hidup Lansia Yang Tinggal Bersama Keluarga Dan Panti. Jurnal Pendidikan Keperawatan Indonesia, 1(1), 1. Https://Doi.Org/10.17509/Jpki.V1i1.117 8. 
Setyowati, R. (2019) Psikolog/ Dosen Psikologi FK UNS

Siregar, P, S. 2020. https: //www. mutupelayanankesehatan.net/19headline/3423-lanjut-usia-dan-memori

Stanley, M., Beare, Patricia. (2012) Buku ajar keperawatan gerontik. Edisi 2. Jakarta: EGC

Williams, P. (2012) Basic Geriatric Nursing. China: Elsevier.

Yosep I. (2009) Keperawatan Jiwa (Edisi Revisi). Bandung: PT Refika Aditama. 